\title{
Dismissing class
}

\author{
Media representations of workers' conditions \\ in the Global South
}

\author{
Vladimir Cotal San Martin
}

School of Humanities, Education and Social Sciences, Örebro University, Sweden

\begin{abstract}
Neoliberal globalisation has expanded transnational corporations' (TNCs) boundaries of operation and sphere of exploitation, particularly in the Global South where much of the production of traditional TNC manufacturing now occurs. In this article, using a longitudinal approach, I conduct a detailed critical discourse analysis of a large Swedish press corpus reporting on TNC activities in Global South countries. The analysis suggests that the issue of workers' conditions is made relevant to the Swedish public through a "consumer framework" that not only confers proximity and relevance on the topic, but also effectively recontextualises agency and responsibility towards particular or individual social actors, obscuring the class dimension of labour relations and global production. Moreover, rooted in a highly problematic colonial imagery, exploitation in the Global South is seen as a "cultural problem" of "them" rather than a problem related to the social and spatial relations of global capitalism.
\end{abstract}

Keywords: transnational corporations, working conditions, Global South, critical discourse analysis, newspapers

\section{Introduction}

The shift from Keynesianism to a neoliberal form of global capitalism during the last four decades, driven by transnational corporations (TNCs), has resulted in major changes for workers, workplaces, and labour markets worldwide (Harvey, 2005; Saad-Filho \& Johnston, 2005). Neoliberal globalisation has expanded TNCs' boundaries of operation and sphere of exploitation, particularly in the Global South where much of the production of traditional manufacturing in and for TNCs now occurs, often within a business model relying on global supply chains (Smith, 2016). The basic relation of exploitation between capital and labour (Marx, 1887/1986) has largely become a relation between Northern capital and Southern labour. In this article, using a longitudinal approach, I conduct a detailed critical discourse analysis (Fairclough, 2003; van Leeuwen, 2008) of a large Swedish press corpus reporting on the activities of TNCs such as Apple, Nike, and H\&M in Global South countries.

Cotal San Martin, V. (2021). Dismissing class: Media representations of workers' conditions in the Global South. Nordicom Review, 42(S3), 35-55. https://doi.org/10.2478/nor-2021-0025 
Previous research on mainstream news media coverage of workers' and workingclass issues has found that mainstream news media rarely explicitly discuss class or the class conflicts found in society (Mantsios, 1995; Martin, 2004). Consequently, the lives and problems of the working class are largely ignored (Jakobsson \& Stiernstedt, 2018; Kendall, 2011; Martin, 2019). Where there is coverage of the working class, workers, and workers' issues in the news media, scholars have documented patterns of negative attention, misrepresentation, and exclusion of workers' concerns and perspectives (Beharell \& Phillo, 1977; Bekken, 2005; Glasgow University Media Group, 1976, 1982; Parenti, 1993; Puette, 1992). However, much of the research on workers and workers' issues in the news has centred on industrial disputes and labour conflicts in the Global North, primarily contributing to an understanding of worker- and labour-related issues in these areas. Few studies specifically examine and analyse the mediated representation of workers and working conditions in the Global South (Cotal San Martin \& Machin, 2020), and those that do focus primarily on the "sweatshop" framing and not on representing workers and working conditions in the Global South more generally (Greenberg \& Knight, 2004; Guo et al., 2012).

This issue of workers' conditions in the Global South has become of particular concern, since the liberalisation of trade has made it easier for TNCs, which seek to reduce production costs by taking advantage of the wage hierarchy between the Global North and South, to extend their global supply chains to Global South countries (Smith, 2016).

In critical discourse studies, it has been demonstrated that newspapers are fundamental to organising the discourses through which people understand the world (Bell, 1999; Fowler, 1991; Richardson, 2007). Such discourses can be fostered and used for various ideological purposes, such as to legitimise, maintain, or naturalise different forms of social power and inequality (Fairclough, 1992; van Dijk, 1995). While sociologists and media scholars have studied how the ideological content of news may shape the public's idea and understanding of politics, race, and gender in ways that serve those in power, less attention has been paid to how the news may influence how we understand class and class issues in a similar manner (Kendall, 2011).

The departure point of this article is the contention that, while describing and explaining workers' conditions in the Global South to the public, the news media play a central role in shaping public perceptions of workers and their conditions, and of the political and economic actors playing pivotal roles in the mounting exploitation of labour in the Global South. As "ideology producing institutions" (Gramsci, 1971), the news media are key distributors of a set of ideas and images through which we understand the world. Crucially, these ideas and images often reflect and reproduce dominant ideas and values that serve to legitimise, naturalise, and reinforce class domination (Fuchs, 2011; Harper, 2012). The news media are fundamental to the process of legitimising and reinforcing the existing social order by (re)producing discourses serving dominant social interests (Fairclough, 1995; van Dijk, 1995). However, while mainstream news media often help reproduce the capitalist system, the media do not - in any simplistic or deterministic manner - simply reproduce the interests of the powerful, and neither do the powerful speak with one voice (Hall, 1980; Sparks, 2006). It is therefore important to understand and underline how they justify the existing order.

I utilise a critical discourse analysis approach (Fairclough, 2003; van Leeuwen, 2008), in which I relate an entry-level or thematic analysis of key themes and topics in the 
coverage to an in-depth analysis of arguments and discursive strategies (Krzyżanowski, 2010) deployed in the discursive construction of workers' conditions in the Global South. In so doing, this article provides critical insights into how these conditions are represented in newspapers in terms of their relevance (to a national readership) as well as agency and responsibility (i.e., those responsible for working conditions) and the possible ideological impact thereof on readers and their knowledge and interpretation of this issue.

I begin by reviewing the literature to provide context for how TNCs operate and for the global regulatory and finance system that allows them to do so. This is important in order to clearly identify how different forces, processes, causalities, and actors are recontextualised (van Leeuwen, 2008) in news texts. Second, I give a brief account of the representation of the Global South in the news media, helping us understand the nature of the reporting I found.

\section{Neoliberalism, global supply chains, and the exploitation of workers}

The outsourcing of manufacturing production from the West to low-wage countries in the Global South started in the 1960s and 1970s, but intensified with the implementation of neoliberal economic policies around the world in the 1980s (Smith, 2016). Outsourcing is generally considered a reaction to the crisis of Fordist capitalism in the 1970 s, as well as a response to the class conflicts in Europe and the US, where organised labour threatened profits by increasing costs (Munck, 2002; Saad-Filho \& Johnston, 2005). In such a context, expanding to areas in the Global South - with low wages and low production costs - became a conscious class strategy among TNCs (Harvey, 2005; Smith, 2016).

Powerful international institutions, such as the International Monetary Fund, World Bank, and the World Trade Organization, have been crucial in advancing the interests of TNCs by pursuing and enforcing neoliberal policies globally that remove legal and institutional barriers to capital mobility (Peet, 2009). As a result of these neoliberalising policies, TNCs such as Walmart, Nike, Adidas, and H\&M can shift suppliers within and between countries, expanding their boundaries of operation and thereby their sphere of exploitation, affecting millions of workers, particularly in the Global South where networks of production in the form of global supply chains have emerged (Smith, 2016).

Global supply chains have been described as buyer driven, with TNCs being the most powerful actors controlling them and dictating the terms of their operation, aiming at lowering labour costs while increasing output (Anner, 2015). TNCs decide from whom they will source, how much they will pay for products, how soon they need them, and what these products should look like. Supplier factories are therefore under strong pressure from TNCs to deliver cheap, high-quality products with shorter and shorter production cycles. The fact that TNCs can shift between suppliers within and between countries creates a situation in which supplier factories compete against one another on prices to remain "competitive" and be attractive to foreign investment, ultimately at the expense of worker safety and wages (Parenti, 2011; Smith, 2016). To earn profits themselves, supplier factories must implement cost-cutting measures (e.g., pay low wages and provide unsafe working conditions) while forcing workers to work long hours to increase productivity to meet rapid production cycles. 
For decades, numerous studies, reports, and books have been documenting and exposing how cost-cutting measures result in brutal working conditions in global supply chains and export processing zones (EPZs) in the Global South (see, e.g., Andersson Åkerblom \& Kärnstrand, 2016; China Labor Watch, 2011; Hearson, 2009; Human Rights Watch, 2012; Lindström, 2004; SACOM, 2016; Werner \& Weiss, 2005). A vast literature deals with different corporations (e.g., Apple, Samsung, Disney, Nike, Adidas, Walmart, Primark, Carrefour, H\&M, Levi Strauss \& Co., and Zara) and their practices in specific social contexts (e.g., China, Honduras, Guatemala, Bangladesh, India, Sri Lanka, Thailand, Cambodia, and Qatar) and production sectors (e.g., garments, construction, electronics, sportswear, shoes, and toys). Taken together, this literature confirms that worker exploitation is not limited to individual corporations, countries, or factories, but rather is related to how capitalism and this particular business model works (Hoskins, 2014; Sandoval, 2015; Smith, 2016). Violations of workers' rights in the Global South must be seen in a context in which, for example, increasing wages, decreasing working hours, and improving health and safety protection are costs that directly conflict with the aim of profit.

As I analyse the discourses on working conditions in the Global South, such discourses must also be understood in the context of those generally used to represent the Global South in the news media.

\section{The news media and the Global South}

There is a long-standing pattern in the coverage produced by (Western) international journalism whereby Global South countries are largely under-represented in the news (Chang, 1998; MacBride, 1980; Roosvall, 2010), appearing mostly if they can be examined from a domestic angle or when Western people are involved (CARMA, 2006). Coverage therefore tends to be "episodic" and highly selective and fragmented, emphasising certain regions, countries, and hot spots (van Ginneken, 1998).

When there is coverage of the Global South, it is dominated by negative and stereotypical stories of wars, coups, tragedies, disasters, diseases, cruelty, poverty, and suffering (Hafez, 2007; Peterson, 1980; Williams, 2011), without any substantial context, making these events appear almost random and without clear causes (Lugo-Ocando, 2015; van Ginneken, 1998). Such negative and stereotypical stories can be partly explained by how colonialism has shaped the structures and processes underpinning international news gathering (Williams, 2011) and by the criteria and factors guiding the selection of foreign "events" that become "news" - criteria such as drama, conflict, and negativity (Galtung \& Ruge, 1965; Harcup \& O’Neill, 2001, 2017). Crucially, stories about the Global South do not touch upon the role of the global economic system, the legacy of colonialism, ongoing Western economic and political interests, the role of the International Monetary Fund and World Bank, and so forth (Abalo, 2015; Macleod, 2018). Importantly, this lack of context serves ideologically to hide the responsibility of "global" economic and political actors and interests, instead holding "local" actors and interests responsible for their own plight, violence, political and economic instability, and corruption (Hafez, 2007; MacBride, 1980; Williams, 2011), reinforcing simplistic explanations and stereotypes. Underlying these stories is a particular stereotypical colonial imagery whereby people in the Global South are often portrayed as irrational, uncivilised, innocent, hostile, corrupt, poorly organised, and in general deviating 
from the norms of Western rationality (Abalo, 2016; Lugo-Ocando \& Malaolu, 2015; MacLeod, 2019).

Importantly, such colonial stereotypes and representations have historically played a fundamental role in producing knowledge serving Western colonial and imperialist interests (Hall, 1992). By constructing the colonised as people "different" from "us" in terms of both their innocence and friendship as well as their hostility, and as inferior, irrational, uncivilised, and so on, colonial powers could develop ideas about their own superiority (Fanon, 2001; Said, 1978).

\section{Methods and material}

In this article, I use critical discourse analysis to analyse the material. Influenced by the "sociology of language" (Bernstein, 1971) and the "critical linguistics" of the late 1970s (Fowleret al., 1979), critical discourse analysis shares an interest in the role of language in the functioning of society and politics. Language is seen as an important means by which we communicate and create meaning; as it can be used as an ideological instrument to legitimise, maintain, and naturalise forms of social power and inequality (Fairclough, 1995; Wodak, 2008), it is crucial in constructing and sustaining ideologies. Ideologies can be understood as "mental frameworks" (Hall, 1986) or "particular ways of representing and constructing society which reproduce unequal relations of power, relations of domination and exploitation" (Fairclough \& Wodak, 1997: 275) and, in so doing, confer advantages on those with power. Ideology thus concerns the "ways in which meaning is mobilised for the maintenance of relations of domination" (Thompson, 1984: 5).

A key concept here is that of discourse (Foucault, 1979), understood as capturing the kinds of knowledge of the world or the broader ideas communicated by a text. Critical discourse analysis aims to denounce social domination and social inequality by demystifying ideologies and power relations that are more or less buried in discourses (Fairclough, 1995; Wodak, 2013). Such discourses can be thought of as comprising "scripts" (Van Leeuwen \& Wodak, 1999), which are the doings of discourse and include elements such as participants, actions, processes, and causalities. Importantly, discursive scripts can involve the recontextualisation of social practices (i.e., the actual events and processes), in order to align them with specific ideological interests (van Leeuwen, 2008). In this article, the analysis examines the details of language and grammar choices and how these shape the representation of events, processes, participants, and identities in ways that support the maintenance of dominant interests and existing social relations (e.g., class relations).

This analysis can be described, broadly, as comprising two steps or levels. First, an entry-level or thematic analysis (Krzyżanowski, 2010) of key themes and topics of the coverage in Swedish newspapers maps the content of the analysed texts. Second, an in-depth analysis (Krzyżanowski, 2010) treats pragmatic aspects of discourse, notably including various discursive strategies of self-versus-other representation (Reisigl \& Wodak, 2001), the representation of social actors and social action (Machin \& Mayr, 2012; van Leeuwen, 2008), and various argumentative strategies used to argue for and against different discursive constructions of the status quo (Krzyżanowski, 2010).

The key critical discourse analysis categories examined here - albeit in a differentiated manner - chiefly include three categories: topics of discourse, discursive 
strategies of representing social actors and actions, and discursive strategies of argumentation.

Topics of discourse, or themes, summarise the text, specifying its most important information (van Dijk, 1991). A thematic analysis has the general aim of mapping the content of the analysed texts and ascribing them to particular discourses to which they may belong (Krzyżanowski, 2010). In this article, when analysing texts, one must therefore identify what sorts of themes or topics (and sub-topics) are featured in news texts and to which particular discourses they may belong; this entails listing "larger" or general topics in the text, and is an analytical process including several thorough readings of the data (Krzyżanowski, 2010). Through this inductive and systematic analytical process, we see whether we can abstract recurring themes concerning what is being said about workers and working conditions.

Discursive strategies of representing social actors and action encompass how social actors and social actions are represented in news texts. The key categories used in the analysis were proposed by van Leeuwen (2008), and later elaborated on by Machin (2013), as follows: inclusion versus exclusion, individualisation versus collectivisation, aggregation, differentiation, and role allocation. These categories let me be more systematic in considering how social actors are classified in news texts as well as how social actions are attributed to different participants (Machin \& Mayr, 2012).

Discursive strategies of argumentation, or topoi, are classical discourse categories brought into critical discourse analysis via its discourse historical approach tradition (Krzyżanowski, 2010; Reisigl \& Wodak, 2001). An argumentation-oriented analysis of topoi is intended to "reveal how different elements of discourse are endowed with pragmatic meaning and thus placed within different arguments according to the moreor-less strategic aims set up by the speakers/authors of texts" (Krzyżanowski, 2010: 83). Topoi are parts of argumentation that connect the argument to the conclusion (Reisigl \& Wodak, 2001). In that sense, a particular topos summarises as well as justifies a particular line of argument by linking it to the background knowledge of the reader. For example, the topos of local (ir)responsibility in the Global South allows one to argue that violations of working conditions are attributable to Global South local actors' irresponsibility, an accusation widely used in the Western world as a token of a specific post-colonial "Third World" perception of the Global South.

Furthermore, the analysis also focuses on the lexical aspects of studied media representations by exploring specific words used to support discursive strategies (e.g., as part of naming or labelling individuals and groups, predicating their features, and describing contexts and events) (Reisigl \& Wodak, 2001; Richardson, 2007). The analysis also includes "headline analysis" (Bell, 1999; van Dijk, 1988), which often captures thematic frames that determine the contents as well as the wider ideological tone of media representations.

The analysed material derives from six Swedish newspapers: Dagens Nyheter $(D N)$, Svenska Dagbladet (SvD), Aftonbladet (Ab), Expressen (Exp), Göteborgs-Posten (GP), and Sydsvenska Dagbladet (SSD). These sources were chosen because they are Sweden's largest-circulation newspapers (Weibull et al., 2018). The study period is the two years, from 1 January 2012 to 31 December 2013. This choice of period was intentional, motivated by a desire to capture tendencies in reporting within a significant time period (here, 24 months). 
In total, the corpus comprises 32 news texts: nine from $D N$, seven from $S v D$, five from $G P$, seven from $S S D$, two from $\operatorname{Exp}$, and two from $A b$. This material was collected from Mediearkivet (Retriever), Scandinavia's largest digital archive of media sources. Initially, to search broadly, two keywords were used: "arbetsförhållanden" [working conditions] and "globalisering" [globalisation]. This generated 531 total hits, many or which were irrelevant to the analytical aims. For instance, news texts might contain the keywords arbetsförhållanden and globalisering, but not be about working conditions in the Global South. I therefore proceeded with a strategic selection based on the criterion that the content of the news texts - at the headline and lead or introduction levels - must contain information about workers' working conditions in the Global South, in relation to TNCs. This procedure eventually reduced the material to 32 texts subsequently subjected to in-depth qualitative analysis in the original language, Swedish. The material was not collected in a genre-specific way, so these texts include news articles, opinion pieces, and short notices. Although different genres have different styles of writing, the present focus is not on these differences per se, but rather on how all these texts collectively represent workers' working conditions in the Global South - in whatever narrative styles appear.

\section{Results}

The analysis below comprises two parts. The first presents the results of the entry-level or thematic analysis (Krzyżanowski, 2010) that maps the content of the analysed texts to give an overview of the key themes and topics of the coverage of working conditions in the Global South in Swedish newspapers. The second part, building on the previous thematically ordered analysis, presents the results of the in-depth analysis (Krzyżanowski, 2010) of arguments and discursive strategies deployed in discursive constructions of workers' conditions, by highlighting some of the key, general aspects of the discursive construction of workers' conditions in the data.

\section{Working conditions: Theme and topics}

The general structuring of the discourse on working conditions in the Global South thematically encompasses various parts of the production industry to illuminate how the workers and their working conditions are eventually presented and constructed. While some news texts in the data concern the food, furniture, and toy industries, most news texts concern the garment and electronics industries. Located within a general industry-specific framing, the discourse on worker conditions is further particularised within specific topics of discourse. Table 1 summarises the theme and topics as well as the core information provided by the news texts in relation to each topic. 
Table 1 Topics and sub-topics within the general theme "workers/working conditions"

\begin{tabular}{|c|c|}
\hline Topic & Sub-topics and lexical choices \\
\hline Working conditions & $\begin{array}{l}\text { - excessive working hours } \\
\text { - environmental dangers; toxic chemicals; insufficient safety equipment } \\
\text { - harassment and abusive practices } \\
\text { - poor, miserable, deplorable, abominable, and inhuman }\end{array}$ \\
\hline Pay & $\begin{array}{l}\text { - low wages } \\
\text { - minimum wage } \\
\text { - starvation wages } \\
\text { - not a living wage }\end{array}$ \\
\hline Employment conditions & $\begin{array}{l}\text { - deceptive contracts } \\
\text { - precarious } \\
\text { - sub-contracts } \\
\text { - short contracts }\end{array}$ \\
\hline Housing & $\begin{array}{l}\text { - shanty towns } \\
\text { - small dormitories } \\
\text { - huts } \\
\text { - sanitary problems }\end{array}$ \\
\hline Workforce composition & $\begin{array}{l}\text { - young } \\
\text { - women } \\
\text { - migrants } \\
\text { - children }\end{array}$ \\
\hline Worker organisation & $\begin{array}{l}\text { - dangerous } \\
\text { - risk to life } \\
\text { - harassment } \\
\text { - threat }\end{array}$ \\
\hline
\end{tabular}

As seen in Table 1, six topics both construct and structure the discourse about workers' conditions in the Global South: 1) working conditions, 2) pay, 3) conditions of employment, 4) housing, 5) workforce composition, and 6) worker organisation. Each of these six recurring topics contains sub-topics related to the main theme as well as recurrent lexical choices at the textual micro-level that describe the overall working situation of workers in the Global South. If we look, for instance, at one topic from the table to exemplify this, namely, working conditions, we see that the main sub-topics are the number of hours workers work, the environmental dangers they are exposed to in the workplace, and the existence of various harassing and abusive practices by superiors. The most common lexical choices used to describe the overall situation of workers in their workplaces are as follows: poor, miserable, deplorable, abominable, and inhuman. Taken together, all the above sub-topics and lexical choices illustrate the core information provided by the news texts in relation to each topic. Table 1 shows that there is explicit exposure and acknowledgement of the severe working conditions in the Global 
South in the totality of the analysed texts conveyed through addressing different topics and themes. However, when analysing the data in more depth (Krzyżanowski, 2010), this exposure is often followed up in specific articles using different argumentative strategies that can be critically interpreted as justification serving ideological aims. It is important to understand that the content oscillates between a discursive strategy of exposing severe working conditions in the Global South and, although not completely overt, partly justifying the same conditions. One example illustrates how these argumentative strategies are typically deployed in the material (see Appendix 1 for excerpts in original Swedish): ${ }^{1}$

\section{Excerpt 1}

The conditions for employees in toy factories are similar to those in other industries in China [...] Seen through Western eyes, working conditions are poor, not to mention how much worse they were ten or twenty years ago. Nevertheless, the factories constituted a temptation for poor rural residents. Despite the low wages, millions of residents earned money that lifted them out of poverty [italics added]. (Petersson, DN, 1 December 2012)

In this example, we are told in the first sentence that the conditions for "employees in toy factories" in China are "similar to those in other industries" in the country. One possible interpretation is that the severe working conditions in the toy industry are "no worse" than those in other industries in the country. If these working conditions are no worse than those in other industries, but rather similar to them, then these conditions may be interpreted as "normal" in that particular context. That this is not an accidental interpretation of this part of the news text is reinforced by the next sentence, in which the conditions are said to be poor, "seen through Western eyes". According to this news text, it is in the Western world in particular that these conditions are viewed as poor, implying that people elsewhere may not agree with such a view. For non-Westerners, these conditions may very well be "normal". We also see in the same sentence that, even though these conditions are exposed and recognised as poor, the reader is simultaneously implicitly told that they actually improve on conditions in previous periods, as they were much worse "ten or twenty years ago". The last sentence of the above example points specifically to how "beneficial" working opportunities have been for "millions of people" that they have "lifted out of poverty". The use of numbers here, together with the generic term "people" in "millions of people" who have been lifted "out of poverty", gives the impression of scientific credibility (Machin \& Mayr, 2012), although the reader cannot know with certainty whether, for instance, it is one million or tens of millions, or what particular "people" actually have been "lifted" out of poverty.

The preferred meaning of this example is arguably that working conditions - albeit poor - are "normal", an "improvement", and an "opportunity to lift people out of poverty" in a particular country. This example is typical of how news texts on working conditions in the Global South in the Swedish press present a superficial sense of being critical or reflective, although closer analysis reveals how they simply recontextualise events, processes, and motives. This happens mainly through use of a "consumer framework". 


\section{Constructing relevance: The consumer framework}

There is a pattern in the news texts whereby the coverage of workers' conditions in the Global South is made relevant to the Swedish public via the "domestication" of the foreign reality (Clausen, 2004; Gurevitch et al., 1991; Olausson, 2014) through a "consumer framework". The consumer framework creates proximity between poor working conditions abroad and the Swedish public by focusing on particular commodities made in poor working conditions, such as iPhones, computers, T-shirts, or jeans. Transverse relations are established in the news coverage between workers' conditions in the Global South, the particular products available in the Swedish national market, and the Swedish public constructed and referred to as consumers.

This particular consumer framework is often established even at the headline level in the studied news texts. In the top-down hierarchical structure of news texts (van Dijk, 1988), headlines are designed to attract the reader, usually abstracting the main point of a news story (Bell, 1999). As such, headlines give the reader a framework and signal the preferred meaning of a news text (van Dijk, 1988), which "helps the reader to set down the ideological criteria by which the reader is to 'make sense' of what follows" (Allan, 2004: 83). Excerpt 2 below illustrates typical headlines from the data:

\section{Excerpt 2}

H1. Children pay for our cheap products (Alsén, Exp, 8 December 2013)

H2. The price of our favourite wines: poor conditions for the workers (Delin \& Löfgren, DN, 18 July 2013)

H3. Here is where the Christmas gifts you buy are made (Petersson, DN, 1 December 2012)

H4. Our fashionable jeans claim lives (von Hall, SvD, 9 May 2012)

H5. A high price for lower prices: inhuman working hours, dangerous workplaces, and starvation wages behind cheap tablets and mobile phones (Spaak, GP, 7 July 2012)

The above quotations show that the ideological criteria by which readers are to "make sense" of what follows are constructed from the perspective of "consumers" with a focus on the products they may buy. All the examples (H1-H5) illustrate how readers in Sweden are actively positioned as consumers in relation to workers' working conditions in the Global South. In H1, the reader is implicitly a consumer, and as such, a potential buyer of "cheap products" made by children. In $\mathrm{H} 2$, the reader is implicitly a potential consumer of "favourite wines", yet at the price of "poor working conditions for the workers". In H3, the reader is referred to by the second-person "you" and is once again implicitly a potential consumer, this time of Christmas gifts. In H4, the reader is implicitly a potential consumer of "fashionable jeans" that come at the price of death. And in H5, the reader is assumed to be a consumer of "cheap tablets" and "mobile/ smartphones" that come at a "high price: inhuman working hours, dangerous workplaces, and starvation wages". This dominant consumer framework, clearly visible even at the headline level, has further implications for how the readers are constructed and referred to in the particular context of the news texts. 


\section{Addressing or positioning readers as consumers}

There are always different choices for how to describe readers in news texts, and these choices could influence how readers perceive themselves and "make sense" of their relations to particular news stories (Machin \& Mayr, 2012; Richardson, 2007). Analysing such lexical choices is important, as they can reveal the sorts of identities being constructed in the news. In the studied data, readers are predominantly positioned, constructed, or referred to as consumers. Importantly, the construction of the reader as consumer is often an implicit discursive strategy, occurring in a subtle way in the texts, as the following excerpt illustrates:

\section{Excerpt 3}

How expensive can a cheap sweater get? The red one that was a bargain, or the jacket that cost nothing, or the child's pyjamas that were so cheap that you bought three items. Made in Bangladesh of course [italics added]. (von Hall, SvD, 8 May 2013)

In this example, the text constructs a relationship between the writer and the reader via a shared experience: buying cheap products. This shared experience is linguistically constructed by using the Swedish word "man" (you) - an impersonal "you" that does not specify who is actually "buying" but rather implies an experience shared by the journalist and the reader: being a consumer of cheap products. Without overtly stating that the reader is in fact a consumer, the text positions and constructs the reader as such. A similar discursive strategy in which the reader is an implied consumer can be seen in Excerpt 4:

\section{Excerpt 4}

No matter what phone you choose, it has been manufactured in poor working conditions. Starvation wages, inhuman working hours, and dangerous workplaces. That is the reality behind many of the electronics we daily have around us [italics added]. (Spaak, GP, 7 July 2012)

Here, we see a discursive strategy in the text from which the implied consumer cannot "escape" (e.g., Berglez, 2013). This "inescapability" is achieved linguistically in the first sentence: "No matter what phone you choose, it has been manufactured in poor working conditions [italics added]". The reader is directly addressed in this sentence in the second-person singular "you". According to this text, it does not matter what phone "you" choose, they are all produced in these conditions. It follows from this argument that the reader, as an implied consumer, cannot escape that fact. Such inescapability is often created in news items to create relevance and invoke proximity between a foreign event and a national local audience (see, e.g., Berglez, 2013). The pronoun "we" in the last sentence of the above example - "That is the reality behind many of the electronics we daily have around us [italics added]" - creates and establishes a commonality of experience between the writer and the reader, the commonality of being consumers surrounded by products made in poor working conditions.

Framing workers' working conditions in the Global South within a consumer framework gives the topic proximity and relevance. However, it also has ideological implications, not only by (re)producing a consumer identity, as shown above, but also through 
constructing responsibility for working conditions in the Global South and through the arguments presented as "solutions" to the problem in the studied data.

\section{Constructing responsibility}

There are two common explanations for how the analysed material highlights the social actors identified as majorly responsible for working conditions abroad. The first dominant explanation is that consumers, by consuming, demanding, and desiring these products, help perpetuate horrible working conditions abroad. The second dominant explanation is that "unethical" "local" social actors in the Global South are the ones creating the terrible working conditions. Both explanations conceal the structural, institutional, and corporatist responsibility for the global exploitation of workers and serve, ideologically, to effectively and strategically shift responsibility from the wider global system of capitalist-driven exploitation towards individual social actors (i.e., consumers and local factory owners in the Global South). The following excerpts illustrate how this typically happens in the analysed material, in both subtle and more explicit manners.

\section{Blaming it on consumers}

\section{Excerpt 5}

In 2007, China's toy industry was shaken. Lead had been discovered in the paint of many toys that were exported. Toxic toys were recalled in large quantities. "Not made in China" became a concept implying safety and quality and a chance for manufacturers in other countries. Five years later, 80 per cent of the world's toys are now manufactured in China. The reason is as usual: the price. Because who wants to pay twice as much for a doll? [italics added]. (Petersson, DN, 1 December 2012)

In Excerpt 5, we are told that China's toy industry experienced difficulties in 2007 after lead was found in the paint used on many toys. We are also told that five years after that, 80 per cent of all toys produced around the world were made in China. The "reason" that this text identifies is worth noting. By the end of the above example, the text states that the "reason" is the "price". The rhetorical question in the last sentence - "Who wants to pay twice as much for a doll?" - suggests that the writer presupposes that it is consumers who are responsible for production being set up in China, as they would not want to pay twice as much for a doll. In this subtle manner, consumers are implicitly held responsible for working conditions abroad because they are not only potential buyers of such products, but are also the ones demanding cheap products. This discursive strategy, which effectively shifts responsibility away from the business model and TNCs towards the individual consumer, narrows down responsibility to the individual level.

Consequently, the suggested "solutions" to the problem are also typically narrowed down to the individual in the news texts:

\section{Excerpt 6}

As consumers, we should ask questions, request transparency, and demand that better working conditions be introduced in textile factories [italics added]. (von Hall, SvD, 8 May 2013) 
Although it is not specified to whom questions should be asked, how transparency can be requested, or of whom we can demand that better working conditions be introduced, we can understand that this is implicitly in relation to TNCs. It is assumed that consumers have the power to change workers' working conditions in the Global South by asking questions. The focus on individual consumers constructs them in a contradictory manner: individual consumers are often envisioned in the analysed material as both responsible for workers' working conditions abroad and having the power to change these conditions. This contradictory position is illustrated in Excerpt 7:

\section{Excerpt 7}

But imagine if we consumers were only able to grow up and start taking our own responsibility [...] Instead of deflecting the responsibility issue further, we should start to question our own choices [...] Then perhaps the popular abbreviation of corporate social responsibility, CSR, could be broadened to also encompass consumer social responsibility. A good thing is that it would put even more pressure on companies to do well and take responsibility [italics added]. (Frostberg, SSD, 24 August 2013)

This example begins, "But imagine if we consumers". Similar to what we saw in Excerpts 3 and 4, the use of the pronoun "we" together with "consumers" creates commonality between the writer and the reader, as fellow "consumers". This is followed by, "were only able to grow up and start taking our own responsibility". Interestingly, in this sentence, "consumers" are presented as needing to "grow up and start taking our own responsibility". These words treat consumers as children who need to grow up, presupposing that they do not take enough responsibility, but should do so. The focus in this text, that the consumer should take responsibility for the matter, is elaborated on in the next sentence: "Instead of deflecting the responsibility issue further, we should start to question our own choices [italics added]". This sentence places the responsibility on individuals, as consumers, to start questioning their own choices, turning the global problem of working conditions into an individual question, rather than calling on individuals to question, for instance, the business model or TNCs. In fact, the preferred strategy of the article from which this example comes is to shift the focus away from corporate responsibility to consumer responsibility. This also occurs in the last part of this example, when the writer says that corporate social responsibility could expand to encompass "consumer social responsibility". This presupposes that such a consumer attitude would "put even more pressure on the companies to do well and take responsibility", implying that consumers have both the responsibility and power to change the behaviour of corporations. Both Excerpts 6 and 7 rely on the idea of the powerful consumer capable of dictating production, aligning with neoliberal ideas of powerful individuals (Harvey, 2005).

\section{Blaming it on the "locals"}

When looking at how participants are represented in the news texts as doing something or not doing anything (i.e., being active or passive) - shaping how the reader perceives social actors, events, and circumstances, and possibly aligning the reader with or against particular actors (Hansen \& Machin, 2013; Machin \& Mayr, 2012) - the analysis finds 
that Western participants (often Swedish social actors in the form of Swedish TNCs) are typically represented as active agents, willing to overcome poor working conditions in the Global South. In contrast, "local" social actors are often constructed as responsible for the horrific working conditions. In this sense, a positive self-representation and simultaneous negative-other representation are constructed in relation to nationality, both explicitly and implicitly. Aligning with previous colonial and postcolonial imaginaries, in which the West represents reason and rationality while the "others" are assumed to be inferior and expected to learn more rational behaviour: Western (here, Swedish) social actors are typically the rational ones, while social actors in the Global South are irrational. This topos of local (ir)responsibility in the Global South permits claims that the violations of working conditions are a case of Global South local actors' irresponsibility. The following excerpt illustrates how this typically occurs in news texts:

\section{Excerpt 8}

Anyone would feel bad about Chinese bosses who do not think they need to talk to the workers at all, 30-40-degree heat, and not even permission to leave to drink some water, says Andersson [italics added]. (Olsson, SvD, 23 October 2012)

Excerpt 8 quotes a trade union representative describing the desire of H\&M and the Swedish trade union IF Metall to work to improve conditions in Chinese-owned factories in Cambodia where H\&M products are manufactured. According to Richardson (2007), quotations can be used to reinforce the overall meaning the writer is trying to communicate, while making the presentation appear "objective", because they do not express the opinions of the writer. In this quotation, the source foregrounds the nationality of the bosses: "anyone would feel bad about Chinese bosses who do not think they need to talk to the workers at all [italics added]". They are not "capitalist bosses", but "Chinese bosses", and the term "boss" sounds somewhat informal and unofficial, invoking a discourse of Orientalism and associations with the Global South as disorganised, informal, and unregulated (Said, 1978). In the sense of van Leeuwen (2008), this excerpt implicitly relieves H\&M of any responsibility for poor working conditions abroad; instead, the source attributes that responsibility mainly to the irresponsible actions of the "Chinese bosses".

In this quotation, and in the rest of the text, the actions of the "Chinese bosses" are not explained in terms of capitalist relations, but rather by highlighting the bosses' nationality. This suggests that the existing problems of poor working conditions should be understood in this news article - and typically in the analysed material - primarily in "cultural terms" or as due to "cultural differences" between "Swedes" (or Westerners) and "others", with the former represented as superior, as the following example illustrates:

\section{Excerpt 9}

That is why the project is now starting so that the Cambodian parties will learn to socialise in a respectful manner. Swedish negotiating methods, safety representatives, and protection committees do work [italics added]. (Olsson, SvD, 23 October 2012)

In this excerpt, we see that the Cambodians are depicted as unable to "socialise in a respectful manner" and therefore as needing to "learn" this behaviour. The problem of 
poor working conditions becomes a "cultural" problem of "behaviour" rather than a problem of capitalist exploitation and different class interests. This article suggests that existing problems of poor working conditions can be solved by "teaching" the Cambodian parties to relate to each other and by implementing "Swedish negotiation methods". Note again the explicit nomination of the nation, as in "Swedish negotiation methods [italics added]". This reinforces a popular belief among the Swedish population that their country, culture, and values - as well as, in this case, their capitalists (i.e., H\&M) - are superior to those of other nations. It also reinforces the colonial understanding of actors in the Global South as needing "our help". Only "we" can save them. "We", in this news text, refers to rational and reasonable "Swedes", and "we" can teach them to behave and act in a rational and reasonable "Swedish way". Therefore, "we" need to "export" this "Swedish model". The underlying message is that if the "others" implement the "Swedish model", then capitalists and workers will be fine. This article rests on an ethnocentric perception that turns the exploitation of workers into a cultural problem rather than a problem of capitalism, in turn distracting readers from both the responsibility of H\&M as well as the deeper global economic structures that govern trade.

\section{Conclusions}

In this article, I aimed to provide critical insights into how working conditions in the Global South are represented in Swedish newspapers in terms of relevance (to a national readership) as well as agency and responsibility (asking who is responsible for the working conditions), and the possible ideological impact thereof on readers and their knowledge and interpretation of this issue. The results indicate that workers' working conditions in the Global South are presented within a consumer framework. By linking Swedish consumers to the exploitation of workers in the Global South, the coverage gives the topic proximity and relevance. However, while this consumer framework "domesticates" the foreign reality - potentially resulting in engagement in the Global South - it also creates an ideological prism through which the social problem of working conditions in the Global South is seen and explained.

The coverage fails to set the systematic problem of working conditions within the wider context of a global capitalist economy, and it fails to offer a critical interpretation of the business model promoted and used by TNCs and key international organisations. Instead, the exploitation and oppression of workers is recontextualised and strategically presented to be understood as a consequence of the wrongdoings of various social actors, in both the West (in the form of consumers) and the Global South (in the form of local social actors).

One defining feature of the capitalist, neoliberal ideology embraced globally since the 1970s is the displacement of agency from structural causes to individuals (Harvey, 2005). The consumer framework identified here shifts agency and responsibility for working conditions to the individual level. Consumers collectively appear in the coverage as a powerful social actor bearing considerable guilt and responsibility for working conditions abroad - for both demanding and purchasing cheap products - but, importantly, simultaneously envisioned as having agency and power to change those conditions.

Emphasising their consumer role ideologically encourages readers to think of themselves as consumers and redirects their attention towards their individual responsibility, 
making them complicit in terrible abuses of workers. The focus on particular individual responsibility may also lead to an oversimplification of the problem itself, as it becomes a problem that ought to be understood as caused by individual behaviour that is not systematic and can be corrected by individuals themselves. As such, the consumer framework effectively illustrates how the neoliberal discourse of greater individual responsibility is incorporated into how the topic is represented, simultaneously diverting attention from economic institutions and the very system in which TNCs operate. Such recontextualisation of agency and responsibility towards particular individual social actors in media coverage can also be seen as a strategic element of a neoliberal discourse that denies the conceptualisation of the studied problem from a class perspective.

The focus in the coverage on the responsibility and actions of local social actors in the Global South can also be seen as functioning ideologically, as this also helps shift responsibility from TNCs to local contract manufacturers. The characteristics of these social actors (e.g., irresponsibility, corruption, and irrationality) are strategically - and misleadingly - related to nationality or culture, instead of the economic demands that de facto dictate various patterns of behaviour. This not only (re)produces an existing and well-established colonial imagery of underdeveloped "others", but also gives the impression that the problem of worker exploitation in the Global South is essentially "their" "cultural problem", rather than a systematic problem related to endemic global capitalism. As such, these representations "nationalise" oppression and shift the discussion towards national culture or "cultural differences" between "us" and "them" rather than considering actions emanating from deeper economic structures rooted in the socially and economically faulty global business model. In this manner, the news coverage effectively recontextualises - but also normalises - the conflict between capital and labour: it relates this conflict to the sphere of culture, where oppression becomes not so much the result of the class conflicts inherent in capitalism, but the result of wrong "culturally driven" and "culturally conditioned" decisions made by "them" in the Global South. The existence of poor working conditions is framed as having nothing to do with the business model promoted by TNCs and international organisations, but as due to a lack of management skills on the part of suppliers.

\section{Note}

1. All excerpts have been translated from Swedish by the author.

\section{References}

Abalo, E. (2015). Through a post-political gaze - On the ideological loading of democracy in the coverage of Chávez Venezuela. Örebro: Örebro University.

Abalo, E. (2016). Through Eurocentric logics. Journal of language and politics, 15(1), 94-115, https://oi. org/10.1075/jlp.15.1.05aba.

Allan, S. (2004). News culture. Berkshire, UK: Open University Press.

Alsén, D. (2013, December 8). Barnen som får betala priset för våra billiga varor [Children pay for our cheap products]. Expressen, 40.

Andersson Åkerblom, T., \& Kärnstrand, M. (2016). Modeslavar: Jakten på billigare kläder [Fashion slaves: The hunt for cheaper clothes]. Stockholm: Leopard.

Anner, M. (2015). Stopping the race to the bottom. In International Policy Analysis (pp. 1-10). Bonn: Friedrich Ebert Stiftung. https://ler.la.psu.edu/gwr/documents/AnnerRacetotheBottom.pdf

Beharell, P., \& Phillo, G. (Eds.). (1977). Trade unions and the media. London: Palgrave Macmillan.

Bekken, J. (2005). The invisible enemy: Representing labour in a corporate media order. Javnost - The Public, 12(1), 71-84, https://doi.org/10.1080/13183222.2005.11008883 
Bell, A. (1999). The language of news media. Oxford: Blackwell Publishers.

Berglez, P. (2013). Global journalism: Theory and practice. New York: Peter Lang. Global journalism: theory and practice. New York: Peter Lang

Bernstein, B. (1971). Class, codes and control (vol. 1). London: Routledge.

CARMA. (2006). The CARMA report on western media coverage of humanitarian disasters. http://www. imaging-famine.org/images/pdfs/carma_\%20report.pdf

Chang, T.-K. (1998). All countries not created equal to be news: World system and international communication. Communication research, 25(5), 528-563. https://doi.org/10.1177/009365098025005004

China Labor Watch. (2011). Tragedies of globalization: The truth behind electronics sweatshops. http://www. chinalaborwatch.org/report/52

Clausen, L. (2004). Localizing the global: 'Domestication' processes in international news production. Media, Culture \& Society, 26(1), 25-44. https://doi.org/10.1177/0163443704038203

Cotal San Martin, V., \& Machin, D. (2020, November 10). The legitimization of the use of sweat shops by H\&M in the Swedish press. Journal of language and politics. Advanced online publication. https://doi. org/10.1075/jlp.20015.cot

Delin, M., \& Löfgren E. (2013, July 18). Favoritvinernas pris: Usla villkor för arbetarna [The price of our favorite wines: poor conditions for the workers]. Dagens Nyheter, 8-9.

Fairclough, N. (1992). Discourse and social change. Cambridge: Polity Press.

Fairclough, N. (1995). Media discourse. London: Edward Arnold.

Fairclough, N. (2003). Analysing discourse: Textual analysis for social research. London: Routledge.

Fairclough, N., \& Wodak, R. (1997). Critical discourse analysis. In T. A. van Dijk (Ed.), Discourse as social interaction (pp. 258-284). London: Sage Publications.

Fanon, F. (2001). The wretched of the world. London: Penguin Books.

Foucault, M. (1979). The archeology of knowledge. London: Routledge.

Fowler, R. (1991). Language in the news - Discourse and ideology in the press. London: Routledge.

Fowler, R., Hodge, B., Kress, G., \& Trew, T. (1979). Language and control. London: Routledge.

Frostberg, T. (2013, August 24). Dags för konsumenterna att också bli eko-reko [Time for consumers to also become eco-OK]. Sydsvenska Dagbladet, 10.

Fuchs, C. (2011). Foundations of critical media and information studies. London: Routledge. https://doi. org/10.4324/9780203830864

Galtung, J., \& Ruge, M. H. (1965). The structure of foreign news: The presentation of the Congo, Cuba and Cyprus crises in four Norwegian newspapers. Journal of peace research, 2(1), 64-90. https://doi. org/10.1177/002234336500200104

Glasgow University Media Group. (1976). Bad news. London: Routledge/Kegan Paul.

Glasgow University Media Group. (1982). Really bad news. London: Routledge/Kegan Paul.

Gramsci, A. (1971). Selections from the prison notebooks. New York: International Publishers.

Greenberg, J., \& Knight, G. (2004). Framing sweatshops: Nike, global production, and the American news media. Communication and Critical/Cultural Studies, 1(2), 151-175, https://doi.org/10.1080/1479142 0410001685368

Guo, L., Hsu, S.-H., Holton, A., \& Jeong, S. H. (2012). A case study of the Foxconn suicides: An international perspective to framing the sweatshop Issue. International Communication Gazette, 74(5), 484-503. https://doi.org/10.1177/1748048512445155

Gurevitch, M., Levy, M., \& Roeh, I. (1991). The global newsroom: Convergences and diversities in the globalization of television news. In P. Dahlgren, \& C. Sparks (Eds.), Communications and citizenship: Journalism and the public sphere (pp. 195-216). London: Routledge.

Hafez, K. (2007). The myth of media globalization. Cambridge: Polity Press

Hall, S. (1980). Encoding/decoding. In S. Hall, D. Hobson, A. Lowe, \& P. Willis (Eds.), Culture, media, language (pp. 128-138). London: Hutchinson.

Hall, S. (1986). The problem of ideology - Marxism without guarantees. Journal of Communication Inquiry, 10(2), 28-44. https://doi.org/10.1177/019685998601000203

Hall, S. (1992). The west and the rest: Discourse and power. In S. Hall, \& B. Gieben (Eds.), Formations of modernity (pp. 275-332). Cambridge: Polity Press.

Hansen, A., \& Machin, D. (2013). Media and communication research methods. New York: Palgrave Macmillan.

Harcup, T., \& O’Neill, D. (2001). What is news? Galtung and Ruge revisited. Journalism Studies, 2(2), 261-280. https://doi.org/10.1080/14616700118449

Harcup, T., \& O’Neill, D. (2017). What is news? News values revisited (again). Journalism Studies, 18(12), 1470-1488. https://doi.org/10.1080/1461670X.2016.1150193

Harper, S. (2012). Beyond the left-the communist critique of the media. Washington: Zero Books.

Harvey, D. (2005). A brief history of neoliberalism. Oxford: Oxford University Press. 
Hearson, M. (2009). Cashing in: Giant retailers, purchasing practices, and working Conditions in the garment industry. https://cleanclothes.org/resources/publications/cashing-in.pdf/view

Hoskins, T. (2014). Stitched up: The anti-capitalist book of fashion. London: Pluto Press.

Human Rights Watch. (2012). Building a better world cup: Protecting migrant workers in Qatar ahead of FIFA 2022. https://www.hrw.org/report/2012/06/12/building-better-world-cup/protecting-migrantworkers-qatar-ahead-fifa-2022

Jakobsson, P., \& Stiernstedt, F. (2018). Arbetarklassens symboliska utplåning i medelklassens medier [The symbolic annihilation of the working class in middle class media]. Katalys, 42. https://www.katalys.org/ wp-content/uploads/2018/02/No-3.-Arbetarklassens-symboliska-utpl\%C3\%A5ning.pdf

Kendall, D. (2011). Framing class: Media representations of wealth and poverty in America. Lanham, Maryland: Rowman \& Littlefield Publishers.

Krzyżanowski, M. (2010). The discursive construction of European identities. Berlin: Peter Lang.

Lindström, S. (2004). Gränslösa kläder [Clothes without borders]. Stockholm: Bokförlaget Atlas.

Lugo-Ocando, J. (2015). Blaming the victim: How global journalism fails those in poverty. London: Pluto Press.

Lugo-Ocando, J., with Malaolu, P. O. (2015). Africa, that scar on our face. In Lugo-Ocando, J., Blaming the victim: How global journalism fails those in poverty (pp. 85-103). London: Pluto Press.

MacBride, S. (1980). Many voices, one world: Towards a new, more just, and more efficient world information and communication order. Paris: UNESCO.

Machin, D. (2013). What is multimodal critical discourse studies. Critical Discourse Studies, 10(4), 347-355, https://doi.org/10.1080/17405904.2013.813770

Machin, D., \& Mayr, A. (2012). How to do critical discourse analysis: A multimodal introduction. London: Sage.

Macleod, A. (2018). Manufacturing consent for the 2018 elections in Venezuela and Colombia. Media Theory, 2(2), 138-153. https://hal.archives-ouvertes.fr/hal-02047706

MacLeod, A. (2019). Chavista 'thugs' vs. opposition 'civil society': Western media on Venezuela. Race \& Class, 60(4), 46-64. https://doi.org/10.1177/0306396818823639

Mantsios, G. (1995). Media magic: Making class invisible. In P. Rothenberg (Ed.), Race, class and gender in the United States: An integraed study. New York: Martins.

Martin, C. R. (2004). Framed! Labor and the corporate media. Ithaca, New York: Cornell University Press.

Martin, C. R. (2019). No longer newsworthy: How the mainstream media abondoned the working class. Ithaca, New York: ILR Press.

Marx, K. (1986). Capital: A critique of political economy. Moscow: Progress Publishers. (Original work published 1887)

Munck, R. (2002). Globalisation and labour. New York: Palgrave Macmillan.

Olausson, U. (2014). The diversified nature of "domesticated" news discourse: The case of climate change in national news media. Journalism Studies, 15(6), 711-725. https://doi.org/10.1080/146167 0X.2013.837253

Olsson, M. (2012, October 23). Facklig rätt går på export [Trade union law exported]. Svenska Dagbladet, 8.

Parenti, M. (1993). Inventing reality. New York: Saint Martin's Press.

Parenti, M. (2011). The face of imperialism. Boulder, Colorado: Paradigm Publishers

Peet, R. (2009). Unholy trinity - The IMF, World Bank and WTO. London: ZedBooks.

Peterson, S. (1980). A case study of third world news coverage by the western news agencies and the times (London). Studies in comparative international development, 15(2), 62-98. https://doi.org/10.1007/ BF02686375

Petersson, T. (2012, December 1). Här tillverkas klapparna som du köper till jul [Here is where the Christmas gifts you buy are made]. Dagens Nyheter, 28.

Puette, W. (1992). Through jaundiced eyes: How the media view organized labor. New York: ILR Press.

Reisigl, M., \& Wodak, R. (2001). Discourse and discrimination - rhetorics of racism and antisemitism. London: Routledge.

Richardson, J. E. (2007). Analysing newspapers: An approach from critical discourse analysis. New York: Palgrave Macmillan.

Roosvall, A. (2010). What is threatening the West? Islam/communism, religion/politics and the rational/ irrational discourse. In S. A. Nohrstedt (Ed.), Communicating risks: Towards the threat society (pp. 115-136). Gothenburg: Nordicom, University of Gothenburg.

Saad-Filho, A., \& Johnston, D. (Eds.). (2005). Neoliberalism: A critical Reader. London: Pluto Books.

SACOM. (2016). Reality behind brands' CSR hypocricy: An investigative report on China suppliers of ZARA, $H \& M$ and GAP. http://sacom.hk/wp-content/uploads/2018/11/Zara-HM-and-GAP-Full-report.pdf

Said, E. (1978). Orientalism. New York: Pantheon Books.

Sandoval, M. (2015). Foxconned labour as the dark side of the information age: Working conditions at Apple's 
contract manufacturers in China. Communication, Capitalism and Critique, 11(2), 318-347. https://doi. org/10.31269/triplec.v11i2.481

Smith, J. (2016). Imperialism in the twenty-first century: Globalization, super-exploitation, and capitalism's final crisis. New York: Monthly Review.

Spaak, M. (2012, July 7). Ett högt pris för lägre priser [A high price for lower prices]. Göteborgs-Posten, 20-21.

Sparks, C. (2006). Contradictions in capitalist media practices. In L. Artz, S. Macek, \& D. Cloud (Eds.), Marxism and communication studies (pp. 111-132). New York: Peter Lang.

Thompson, J. (1984). Studies in the theory of ideology. Cambridge: Polity.

van Dijk, T. A. (1988). A news analysis: Case studies of international and national news in the press. Hillsdale, New Jersey: Lawrence Erlbaum.

van Dijk, T. A. (1991). The interdisciplinary study of news as discourse. In K. Bruhn-Jensen, \& N. Jankowski (Eds.), A handbook of qualitative methodologies for mass communication research (pp. 108-120). London: Routledge.

van Dijk, T. A. (1995). Power and the news media. In Paletz, D. L. (Ed.), Political communication and action: States, institutions, movement, audiences (pp. 9-36). Creskill, New Jersey: Hampton Press.

van Ginneken, J. (1998). Understanding global news: A critical introduction. London: Sage.

van Leeuwen, T. (2008). New tools for critical discourse analysis. New York: Oxford University Press.

Van Leeuwen, T., \& Wodak, R. (1999). Legitimizing immigration control: A discourse-historical analysis. Discourse studies, 1(1), 83-118. https://doi.org/10.1177/1461445699001001005

von Hall, G. (2012, May 9). Våra moderiktiga jeans skördar liv [Our fashionable jeans claim lives]. Svenska Dagbladet, 15.

von Hall, G. (2013, May 8). Katastrof kan betyda nytt hopp [Disaster can mean new hope]. Svenska Dagbladet, 12.

Weibull, L., Wadbring, I., \& Ohlsson, J. (2018). Det svenska medielandskapet: Traditionella och sociala medier $i$ samspel och konkurrens [The Swedish media landscape: Traditonal and social media in interaction and competition]. Stockholm: Liber.

Werner, K., \& Weiss, H. (2005). Storföretagens svarta bok [The black book of corporations]. Stockholm: Ordfront förlag.

Williams, K. (2011). International journalism. London: Sage.

Wodak, R. (2008). Introduction: Discourse studies - Important concepts and terms. In R. Wodak, \& K. Michal (Eds.), Qualitative discourse analysis in the social sciences. New York: Palgrave Macmillan.

Wodak, R. (2013). Critical discourse analysis: Concepts, history, theory. In R. Wodak, \& M. Meyer (Eds.), Methods of critical discourse analysis. London: Sage 


\section{Appendix 1 Excerpts in original Swedish}

\section{Excerpt 1}

Villkoren för anställda i leksaksfabriker liknar de som gäller för andra branscher i Kina [...] Sett med västerländska ögon är arbetsförhållandena dåliga, för att inte tala om hur mycket sämre de var för tio, tjugo år sedan. Ändå utgjorde fabrikerna en lockelse för fattiga landsortsbor. Trots låga löner tjänade miljontals invånare pengar som lyfte dem ur fattigdom [italics added]. (Petersson, DN, 1 December 2012)

\section{Excerpt 2}

H1. Barnen som får betala priser för våra billiga varor (Alsén, Exp, 8 December 2013)

H2. Favoritvinernas pris: usla villkor för arbetarna (Delin \& Löfgren, DN, 18 July 2013)

H3. Här tillverkas klapparna du köper till jul (Petersson, DN, 1 December 2012)

H4. Våra moderiktiga jeans skördar liv (von Hall, SvD, 9 May 2012)

H5. Ett högt pris för lägre priser - omänskliga arbetstider, farliga arbetsplatser och svältlöner bakom billiga läsplattor och mobiltelefoner (Spaak, GP, 7 July 2012)

\section{Excerpt 3}

Hur dyrköpt får en billig tröja bli? Den röda som var ett fynd, eller jackan som kostade ingenting eller barnpyjamasen som var så billig att man köpte tre stycken. Made in Bangladesh förstås [italics added]. (von Hall, SvD, 8 May 2013)

\section{Excerpt 4}

Oavsett vilken telefon du väljer har den tillverkats under undermåliga arbetsvillkor. Svältlöner, omänskliga arbetstider, och farliga arbetsplatser. Det är verkligheten bakom många av de elektronikprylar $v i$ dagligen omger oss med [italics added]. (Spaak, GP, 7 July 2012)

\section{Excerpt 5}

År 2007 var Kinas leksaksindustri skakad. Bly hade upptäckts i färgen på många leksaker som gått på export. Giftiga leksaker återkallades i stora mängder. "Not made in China" blev ett begrepp för säker kvalitet och en chans för tillverkare i andra länder. Fem år senare tillverkas 80 procent av världens alla leksaker nu i Kina. Anledningen är den vanliga: priset. För vem vill betala dubbelt så mycket för en docka? [italics added] (Petersson, DN, 1 December 2012)

\section{Excerpt 6}

Som konsumenter bör vi ställa frågor, begära transparens och kräva att bättre arbetsförhållanden införs $i$ textilfabrikerna [italics added] (von Hall, SvD, 8 May 2013) 


\section{Excerpt 7}

Men tänk om vi konsumenter bara kunde växa upp och börja ta eget ansvar [...] Istället för att skicka ansvarsfrågan vidare borde vi börja ifrågasätta våra egna val [...] Då kanske den populära förkortningen för företagens samhällsansvar, CSR, skulle kunna vidgas från betydelsen corporate social responsibility till att även innebära consumer social responsibility. Det fina är att det dessutom skulle sätta ännu mer press på företagen att göra gott och ta ansvar [italics added]. (Frostberg, SSD, 24 August 2013)

\section{Excerpt 8}

Vem som helst skulle må dåligt med kinesiska chefer som överhuvudtaget inte tycker att de behöver prata med arbetarna, 30-40 graders värme och inte ens tillåtelse att gå ifrån för att dricka lite vatten, säger Andersson [italics added]. (Olsson, SvD, 23 October 2012)

\section{Excerpt 9}

Därför inleds nu projektet där de kambodjanska parterna ska lära sig att umgås på ett respektfullt sätt. Svenska förhandlingsmetoder, skyddsombud och skyddskommittéer fungerar [italics added]. (Olsson, SvD, 23 October 2012)

(C) 2021 Nordicom and respective authors. This is an Open Access work licensed under the terms of the Creative Commons Attribution-NonCommercial-NoDerivatives 4.0 International Public licence (CC BY-NC-ND 4.0). To view a copy of the licence, visit https://creativecommons.org/ licenses/by-nc-nd/4.0/ 